\title{
Examination of oral biofilm microbiota in patients using fixed orthodontic appliances in order to prevent risk factors for health complications
}

\author{
Konrad Perkowski ${ }^{1, A-F} \oplus$, Wanda Baltaza ${ }^{2, B, D \oplus}$, David Bruce Conn ${ }^{3, E-F \oplus,}$ \\ Magdalena Marczyńska-Stolarek ${ }^{1, B \oplus}$, Lidia Chomicz ${ }^{2, E-F \oplus}$ \\ ${ }^{1}$ Department of Orthodontics, Medical University, Warsaw, Poland \\ ${ }^{2}$ Department of Medical Biology, Medical University, Warsaw, Poland \\ ${ }^{3}$ Department of Invertebrate Zoology, Museum of Comparative Zoology, Harvard University, Cambridge, USA; \\ One Health Center, Berry College, Mount Berry, Georgia, USA \\ A - Research concept and design, B - Collection and/or assembly of data, C - Data analysis and interpretation, \\ $D$ - Writing the article, E-Critical revision of the article, F- Final approval of article
}

\begin{abstract}
Perkowski K, Baltaza W, Conn DB, Marczyńska-Stolarek M, Chomicz L. Examination of oral biofilm microbiota in patients using fixed orthodontic appliances in order to prevent risk factors for health complications. Ann Agric Environ Med. 2019 ; $26(2)$ : $231-235$. doi: $10.26444 /$ aaem/105797
\end{abstract}

\begin{abstract}
Ibstract
Introduction and objective. In recent decades the use of orthodontic appliances in Poland has increased; however, data on their influence on changes of components of the microbiome connected with oral biofilm are scarce. The objective of this study was to evaluate oral microbiota in terms of their role as risk factors for health complications.

Materials and method. The study included 100 patients treated with removable or fixed appliances. Oral hygiene and gingival health were determined, and periodontal swabs taken from each patient for parasitological, bacteriological and mycological microscopic and in vitro examinations.

Results. Oral protists and various pathogenic and opportunistic bacterial and fungal strains were identified in the superficial layer of biofilm. A higher prevalence of bacteria, Enterococcus faecalis, E. faecium, Staphylococcus aureus and Escherichia coli, and various strains of yeast-like fungi from the Candida albicans group, occurred in patients treated with the fixed appliance than in those using a removable appliance or not treated orthodontically. In some periodontal samples from patients treated with fixed appliances, cysts of the Acanthamoeba spp. were found.

Conclusions. The use of orthodontic appliances alters the status of the oral cavity; it has impact on the colonization of oral biofilm by opportunistic/pathogenic strains, and increases the risk of their dissemination to various human tissues and organs. Pretreatment examination of oral microbiome, its monitoring particularly during treatment with fixed appliances, and preventive elimination of the potentially pathogenic strains to avoid health complications, are highly recommended, especially in patients with impaired immunity.
\end{abstract}

\section{Key words}

orthodontical appliances, infectious oral microbiota, risk of health complications, prevention

\section{INTRODUCTION}

In this retrospective interdisciplinary research, the diversity in species of oral biofilm microbiota detected in patients using orthodontic appliances was analyzed in terms of their potentially infectious risk factors for health complications. It is known that the microbiome of the oral cavity may include commensals, symbiotic and potentially pathogenic species from bacteriae, protists and fungi $[1,2,3,4,5,6,7]$.

It should be taken into account that in recent decades the use of orthodontic appliances has increased in Poland. At the same time, no requirements have been specified to assess the risk of impact of potentially pathogenic oral microbiota on the status of the oral cavity before and during treatment with these appliances.

Address for correspondence: Lidia Chomicz Department of Medical Biology Medical University of Warsaw, Poland

E-mail: lidia.chomicz@wum.edu.pl

Received: 23.02.2019; accepted: 15.03.2019; first published: 28.03.2019
The basic indications for the use of orthodontic appliances are: growth modifications, malocclusion treatment, dental arch expansion, correction of minor dental discrepancies. In a healthy oral cavity, individual microorganisms and their micro-colonies adhering to soft and hard surfaces form a biofilm; in these microorganisms, synergistic and antagonistic interactions between resident species occur, including potentially pathogenic strains which remain in relative, dynamic homeostasis $[8,9,10,11,12]$. Fixed appliances are made of brackets, bands and orthodontic arches. Orthodontic brackets can be made of metal alloys and non-metallic materials (composites, ceramic materials), which are fixed in a specific position to the surface of the teeth by a composite adhesive. Orthodontic bands are usually cemented on the first molars. The main part of the orthodontic appliance is located in the vestibule of the mouth, or, in the case of certain types of appliances, in the oral cavity proper. The appliance components impede the self-cleaning of teeth with saliva, promote retention of food debris and 
deteriorate oral hygiene. The accumulation of plaque on components of the appliance increases. Therefore, the use of orthodontic appliances may increase the risk of developing dental caries and periodontal diseases [9, 12, 13, 14, 15].

The development of pathological changes results from the loss of homeostasis of the oral microbiome, and occurs under the influence of many endogenous and external factors, including both the microorganisms and the immunological response of the human body.

Literature data indicate that the use of orthodontic appliances influence the conditions in the oral cavity. In the blood of patients whose fixed braces were removed, opportunistic bacteria, factors of often severe local and systemic diseases were detected $[16,17,18,19]$.

Among the oral microbiota of the analyzed patients with malformations of the masticatory system, Gram-positive $S$. aureus strains [20] were frequently isolated.

The dynamics of bacterial components of the oral microbiome has been investigated for many years in various population groups. However, most of the publications concern pathogens associated with the development of caries and periodontal diseases, considered as civilization diseases; the oral microbiota, not connected with these two groups of diseases, has been studied less frequently [17, 18, 20].

Yeast-like fungi are also found in the oral cavity and are widespread in the human environment; the most common strains are Candida albicans, C. glabrata, C. tropicalis [12, $21,22,23,24]$.

Two species of cosmopolitan parasitic protists: Trichomonas tenax and Entamoeba gingivalis, may occur in the oral microbiome [6, 12, 25, 26, 27, 28, 29, 30, 31], spread by direct contact during a kiss, but also indirectly by commonly used vessels.

Information on the presence of pathogenic and opportunistic microorganisms in the oral cavity is important for evaluating the health risks for patients.

\section{OBJECTIVE}

The aim of the study was to perform a comparative analysis of opportunistic/ pathogenic microbiota able to colonize the oral cavity of patients with orthodontic needs, and to assess the oral microbiota in terms of their role as risk factors for health complications.

\section{MATERIALS AND METHOD}

Comparative analysis of results of this retrospective study concerned 100 persons, aged from 6 to 23 years, who were admitted to the Department of Orthodontics of the Medical University in Warsaw during 2007-2015, and were classified into four groups:

Group I - included 25 orthodontic patients with masticatory system disorders, aged 6-13 years old, treated with removable appliances.

Group II - control group which included 25 patients, also aged 6-13 years, treated conservatively, without the use of appliances.

Group III - included 25 orthodontic patients with masticatory system disorders, aged 14-23 years, treated with fixed appliances;
Group IV - the control group included 25 patients of the same age as in Group III, 14-23 -year, treated conservatively, without the use of orthodontic appliances.

All patients underwent clinical evaluation of the health status by examination of their periodontium, gingiva, presence of inflammatory processes and treatment for tooth decay. Also, for all patients, values of the Plaque Index and Bleeding Index were calculated to assess oral cavity hygiene and gingival inflammation. At the same time, the DMF Index, the common method for assessing the prevalence of dental caries and needs for dental treatment was determined, expressed as the total number of decayed teeth (D), missing (M), or filled (F).

Swabs were taken from 10 sites of the periodontium, dental plaques, and from dental pockets for parasitological, bacteriological and mycological examinations to isolate and identify oral microbiota [31-34]. The wet mount and permanent smears were stained with Giemsa and Trichrome to identify protists based on their morphology. To isolate fungi, Sabouraud substrate was applied, while the identification of species of Candida was performed with Chromagar Candida BBL tests. Preliminary microscopic identification of Grampositive and Gram-negative bacteria strains and in vitro culture techniques were also applied for bacteria specific identification. The swab material was grown aerobically on bacteriological agar and on agar with 5\% defibrinated sheep blood. For recovery and isolation of Staphylococcus strains, Chapman's plate growth medium was applied, and for identification of Enterobacteriaceae, McConkey's medium was used. The prevalence of opportunistic/ pathogenic strains detected in the oral cavities of each group of patients were determined and statistically assessed (Statistica, F-Fisher, HSD-Tukey test; $\mathrm{p}<=0.05$ ).

\section{RESULTS}

In the clinical assessment of the oral cavities of patients treated with orthodontic appliances in Group I and III, occlusion anomalies: prognathism, retrognathism, crossbites, dental discrepancies (crowding, rotations), as well as the accumulation of dental plaque and gingival bleeding, occurred. In all patients, tooth decay of varying intensity was detected. The clinical picture of the oral cavities of patients treated conservatively, without appliances, of control Group II and IV was generally better; however, missing teeth (in younger patients), gingival bleeding, dental caries and gingivitis were noted in some cases.

Pronounced differences in oral cavity conditions were expressed by various values of dental Plaque Index (PI), Bleeding Index (BI) and DMF among patients treated with orthodontic appliances, and those treated conservatively. The values of DMF were considerably higher in patients from Group I treated with removable appliances, compared those in Group II treated conservatively (5.6 and 3.5, respectively; $\mathrm{p}<0.05)$. Bleeding Index was significant higher in older patients from Group III treated with fixed appliances than in those of Group IV treated conservatively (12.7 and 5.93, respectively; $\mathrm{p}<0.05)$. Comparison of the clinical indices for all patient groups analyzed is presented in Table 1.

Examinations of microscopic and in vitro cultured samples of the material obtained from oral cavity swabs showed the 
Table 1. Comparison of the clinical indices for all patient groups analyzed

\begin{tabular}{|c|c|c|c|c|c|}
\hline $\begin{array}{c}\text { Age } \\
\text { (years) }\end{array}$ & $\begin{array}{l}\text { Group of } \\
\text { patients }\end{array}$ & & DMF & Plaque Index (\%) & Bleeding Index (\%) \\
\hline \multirow{6}{*}{$6-13$} & \multirow{3}{*}{$\begin{array}{l}\text { I removable } \\
\text { appliances }\end{array}$} & Mean & $5.6^{*}$ & 47.2 & $12.7^{*}$ \\
\hline & & range & $0-16$ & $11.2-94$ & $0-39$ \\
\hline & & SD & \pm 3.7 & \pm 25.45 & \pm 14.20 \\
\hline & \multirow{3}{*}{ II } & Mean & $3.5^{*}$ & 52.2 & $12.7^{*}$ \\
\hline & & range & $0-10$ & $14.6-97$ & $0-26$ \\
\hline & & SD & \pm 2.5 & \pm 20.56 & \pm 8.07 \\
\hline \multirow{6}{*}{$14-23$} & \multirow{3}{*}{$\begin{array}{c}\text { III fixed } \\
\text { appliances }\end{array}$} & Mean & $9.8^{*}$ & 53.4 & $12.95 *$ \\
\hline & & range & $1-15$ & $6.3-92.6$ & $0-47.2$ \\
\hline & & SD & \pm 3.6 & \pm 28.6 & \pm 12.43 \\
\hline & \multirow{3}{*}{ IV } & Mean & $10.36^{*}$ & 49.05 & $5.93 *$ \\
\hline & & range & $5-18.3$ & $10.8-77.4$ & $0-49.8$ \\
\hline & & SD & \pm 3.71 & \pm 19.05 & \pm 10.40 \\
\hline
\end{tabular}

* statistically significant values of clinical indices in older patients in comparison to the younger, $\mathrm{p}<0.05$

presence of various pathogenic and opportunistic fungal and bacterial strains in the superficial layer of biofilm, as well as in dental pockets. In patients with malformations of the masticatory system, microbial adhesion occurred on the elements of orthodontic appliances.

Among the mouth microbiota of the analyzed patients, typical oral Gram-positive bacteriae of the Streptococcus viridans group were identified.

The yeast-like fungi from the Candida genus, predominantly various strains of $C$. albicans group, were isolated and identified in all patients groups. The greatest prevalence of these fungi was in patients of Group III treated with fixed appliances. There were statistically significant differences in data regarding patients treated and not treated with appliances.

Among bacteriae, Gram-positive of Staphylococcus aureus were identified. Prevalence of C. albicans, compared to $S$. aureus in relation to Bleeding Index in patients treated and not treated with appliances, is presented in Table 2.

Table 2. Prevalence of $C$. albicans and S. aureus in relation to Bleeding Index in patients treated and not treated with appliances

\begin{tabular}{|c|c|c|c|c|}
\hline \multirow{2}{*}{$\begin{array}{c}\text { Age } \\
\text { (years) }\end{array}$} & \multirow{2}{*}{$\begin{array}{c}\text { Group of Patients / } \\
\text { appliance }\end{array}$} & \multicolumn{2}{|c|}{ Patients with the microbiota: } & \multirow{2}{*}{$\begin{array}{l}\text { Bleeding } \\
\text { Index \% }\end{array}$} \\
\hline & & $\begin{array}{l}\text { C. albicans } \\
\% / \text { number }\end{array}$ & $\begin{array}{l}\text { S. aureus } \\
\% / \text { number }\end{array}$ & \\
\hline \multirow{2}{*}{$6-13$} & I/ removable appliance & $12 / 3$ & $8 / 2$ & $12.7^{*}$ \\
\hline & II / without appliance & $8 / 2$ & $4 / 1$ & $7.4^{*}$ \\
\hline \multirow{2}{*}{$14-23$} & III / fixed appliance & $24^{*} / 6$ & $16^{*} / 4$ & $12.95^{*}$ \\
\hline & IV/ without appliance & $8^{*} / 2$ & $8^{*} / 2$ & $5.93^{*}$ \\
\hline
\end{tabular}

*Level of statistical significance set at $\mathrm{p}<0.05$.

There are statistically significant differences in data regarding patients treated and not treated with appliances.

Gram-positive Enterococci: Enterococcus faecalis, E. faecium, and also Gram-negative Enterobacteriaceae: Escherichia coli, Enterobacter cloacae, Pantoea agglomerans, Klebsiella sp., were detected in various patient groups. Comparison of the prevalence of selected Gram-positive and Gram-negative bacteriae from the oral cavities of 14-23 -year- old patients is presented in Table 3.

In the material obtained from oral cavity swabs, live protozoans: Trichomonas tenax and Entamoeba gingivalis
Table 3. Comparison of prevalence of selected Gram-positive and Gramnegative bacteriae from oral cavities of 14-23 -years old patients in relation to Bleeding Index

\begin{tabular}{lcc}
\hline & \multicolumn{2}{c}{ patients with bacteriae } \\
\hline $\begin{array}{c}\text { Group III } \\
\text { number / } \%\end{array}$ & $\begin{array}{c}\text { Group IV } \\
\text { number } / \%\end{array}$ \\
\hline $\begin{array}{l}\text { Enterococci } \\
\text { E. faecalis, E. faecium }\end{array}$ & $8 / 32^{*}$ & $3 / 12^{*}$ \\
\hline $\begin{array}{c}\text { Enterobacteriaceae } \\
\text { P. agglomerans, E. coli }\end{array}$ & $5 / 20^{*}$ & $2 / 8^{*}$ \\
\hline Mean & Bleeding Index in patients of \\
\hline Group III & Group IV \\
\hline SD & $12.95^{*}$ & $5.93^{*}$ \\
\hline & $0-47.2$ & $0-49.8$ \\
\hline
\end{tabular}

* Statistically significant differences in data regarding patients treated and not treated with appliances, $\mathrm{p}<0.05$

were also identified in the older patients, with the low prevalence within the range of $4-8 \%$.

In some periodontal samples from three patients (12.\%) of Group III, double-walled cysts were found and identified as cysts of the amphizoic amoebae - facultative parasitic Acanthamoeba spp..

\section{DISCUSSION}

Comparative qualitative analysis of results of this research revealed clear differences in the prevalence of microbiota strains detected in the oral cavities of particular patient groups.

It is considered that the oral cavity consists of polymicrobial communities, heterogeneous in origin, that can include various endogenous and exogenous species; complex interrelations occur between multilayer components of biofilm, particular species of oral microbiota, and the host organism. Moreover, according to the result of studies involving the oral microbiota metagenomic projects, the oral cavity is one of the most taxonomically diverse sites of the body, in which some infectious species have been identified as protists, fungi and bacteriae [2, 3, 4, 33, 34].

During the last 20 years in European countries, including Poland, in particul the prevalence of fungal infections has significantly increased. Yeast-like fungi of the Candida albicans group are widespread in the human environment; they enter the body through damaged mucous membrane, skin, by inhalation, food and sex. Simultaneously, the components of the fungal cell wall and products released by their cells can inhibit an immune response, which is a serious health risk, even in people with an efficient immune system $[8,21,23,35,36,37]$. A high density of fungi in the mouth, throat and larynx is a serious risk for the spread of fungal diseases.

In the current study there was a clear correlation between the use of fixed appliances and the frequency of isolation of Candida sp. The intensity of C. albicans was correlated with higher values of platelet and bleeding indices, indicating poor oral hygiene and occurrence of periodontitis.

At the same time, in orthodontic patients using fixed appliances, various potentially pathogenic bacteriae of Streptococci and, also Enterococci.groups were detected. 
It should therefore be taken into consideration that the oral cavity may act as a reservoir/source of etiological agents of local infections (abscesses), and also disseminated infections of the urinary tract, bile ducts, endocardium, among others, including nosocomial diseases [7, 20, 30, 32].

The parasitic protozoa Trichomonas tenax and Entamoeba gingivalis were rarely included in clinical studies of the masticatory system; some authors describe them as harmless commensals, despite evidence of the pathological effects of these protests. The destructive impact of these protozoa on oral tissues was detected as their adhesive capacity, high extracellular activity of their proteinases, and distribution of various types of collagen, as well as haemolytic activity on the mucous membrane and other structures of the masticatory system. The protists do not belong to resident microorganisms; they colonize the oral cavity due to invasion that may result in periodontitis, paranasal sinuses. Trichomonads were detected in the content of pulmonary abscesses [25, 26, 27, 28,-29, 31, 38, 39].

It is noteworthy that the Acanthamoeba spp. cysts were also detected in the oral cavities of several patients treated with fixed orthodontic appliances. The results are in agreement with several previous findings [12, 30,39]. Various strains of Acanthamoeba sp. are worldwide facultative parasites that may cause serious threats to human health as etiological agents of granulomatous amoebic encephalitis and visionthreatening Acanthamoeba keratitis.

Amoebae are isolated from the hospital environment, among others, as contaminants of surgical instruments, the dental irrigation system, equipment and accessories in health facilities [30, 39, 40].

\section{CONCLUSION}

In the available literature, data is scarce on the prevalence of various opportunistic bacteriae, parasitic protozoans and yeast-like fungi identified in the oral cavity of people with masticatory system disorders treated orthodontically..

The presented comparative qualitative analysis has shown that the use of orthodontic appliances alters the status of the oral cavity, and impacts on its colonization with different opportunistic/ pathogenic strains.

It should be emphasized that the human oral cavity may act as a major, yet poorly known, reservoir of microorganisms that can induce clinically important infections.

Moreover, as knowledge about the risks generated by components of the oral microbiome is still insufficient, further studies are important to decrease the risk of health complications.

Pretreatment examination of oral microbiota, its monitoring, especially during treatment with fixed appliances, and preventive elimination from mouth of the potentially pathogenic strains to avoid health complications, are highly recommended, especially in patients with impaired immunity.

\section{REFERENCES}

1. Jenkinson HF, Lamont RJ. Oral microbial communities in sickness and in health. Trend Microbiol. 2005; 13(12): 589-595.

2. Zaura E, Keijser BJ, Huse SM, Crielaard W. Defining the healthy'core microbiome' of oral microbial communities. BMC Microbiol. 2009; 9(1): 259-270
3. Belda-Ferre P, Alcaraz LD, Cabrera-Rubio R. The oral metagenome in health and disease. ISME J. 2012; 6(1): 46-56.

4. Lunsford RD, Melillo AA, Somerman MJ. Guest editorial for special oral microbes edition, Microbes Infect. 2015; 17(7): 471-472

5. Sampaio-Maia B, Monteiro-Silva F. Acquisition and maturation of oral microbiome throughout childhood: An update. Dent Res J. 2014; 11: 291-301.

6. Feki A, Molet B, Haag R, Kremer M. Protozoa of the human oral cavity (epidemiological correlations and pathogenic possibilities). J Biol Buccale. 1981; 9: 155-161

7. Zawadzki PJ, Perkowski K, Starościak B, Baltaza W, Padzik M, Pionkowski K, Chomicz L. Identification of infectious microbiota from oral cavity environment of various population group patients as a preventive approach to human health risk factors. Ann Agric Environ Med. 2016; 23(4): 566-569.

8. Stenderup A. Oral mycology. Acta Odontol Scand 1990; 48: 3-10.

9. Mitchell L. Decalcification during orthodontic treatment with fixed appliances - an overview. Br J Orthod. 1992; 19: 199-205.

10. Marsh PD. Dental plaque: biological significance of a biofilm community lifestyle. J Clin Periodontol. 2005; 32: 7-15.

11. Filoche S, Wong L, Sissons $\mathrm{CH}$. Oral biofilms: emerging concepts in microbial ecology. J Dent Res. 2010; 89: 8-18.

12. Perkowski K, Zawadzki PJ, Starosciak B, Dybicz M, Padzik M, Marczynska-Stolarek M, Chomicz L. Składniki mikrobiomu jamy ustnej jako czynniki ryzyka zakażeń lokalnych i uogólnionych u pacjentów bez oraz $\mathrm{z}$ wadami wrodzonymi narządu żucia. Adv Microbiol. 2016; 55(1): 57-67.

13. Remiszewski A, Gordon A, Gieorgijewska J, Goliński A. Warunki zgryzowe i stan stawu skroniowo-żuchwowego u dzieci 7-i 12- letnich. Czas Stomat. 1996; XLIV(12): 834-838.

14. Batoni G, Pardini M, Giannotti A, Ota F, Giuca MR, Gabriele M, Campa M, Senesi S. Effect of removable appliances on oral colonisation by mutans streptococci in children. Eur J Oral Sci. 2001; 109: 388-392.

15. Ahn SJ, Lee SJ, Lim BS, Nahm DS. Quantitative determination of adhesion patterns of cariogenic streptococci to various orthodontic brackets. Am J Orthod Dentofacial Orthop. 2007; 132: 815-821.

16. Demling A, Heuer W, Elter C, Heidenblut T, Bach FW. SchwestkaPolly R, Stiesch-Scholz M. Analysis of supra- and subgingival longterm biofilm formation on orthodontic bands. Eur J Orthod. 2009; 31: 202-206.

17. Perzyńska K, Grygorczuk A, Cwalina L, Herud B. Ocena stanu przyzębia i higieny jamy ustnej pacjentów leczonych aparatami stałymi i ruchomymi. Czas Stomatol. 1996; 49: 636-640.

18. Jordan C, LeBlanc DJ. Influences of orthodontic appliances on oral populations of mutans streptococci. Oral Microbiol Immunol. 2002; 17: $65-71$.

19. Kim K, Heimisdottir K, Gebauer U, Persson GR. Clinical and microbiological findings at sites treated with orthodontic fixed appliances in adolescents. Am J Orthod Dentofacial Orthop. 2010; 137: 223-228.

20. Perkowski K, Chomicz L, Starościak B, Zadurska M, Szałwiński M, Zawadzki P, Piekarczyk P, Olędzka G. Occurrenceof pathogenic bacteria in the oral cavity of the orthodontic patients requiring surgical treatment. Stomatol Współcz 2012; 19: 8-13.

21. Mierzwińska-Nastalska E. Udział mechanizmów odpornościowych w zakażeniach grzybiczych. Prot Stom. 1999; 49: 305-310.

22. Pietrzak-Bilińska B. Grzybice jamy ustnej u dzieci leczonych ortodontycznie. Czas Stomat. 1998; LI(2): 125-132.

23. Kurnatowski P, Tyczkowska-Sieroń E. Wybrane czynniki sprzyjające zarażeniom grzybami w populacji człowieka. Wiad Parazytol. 2004; 50: $367-372$.

24. Nowak M, Kurnatowski P. Biofilm tworzony przez grzyby - struktura, quorum sensing, zmiany morfogenetyczne, oporność na leki. Wiad Parazytol. 2009; 55(1): 19-25.

25. Hersh SM. Pulmonary trichomoniasis and Trichomonas tenax. J Med Microbiol. 1985; 20: 1-10.

26. Čechová L, Leifertova I, Lisa M. The incidence of Entamoeba gingivalis in the oral cavity. Acta Univ Carol Med. 1987; 33: 549-559

27. Linke HAB, Gannon JT, Obin JN. Clinical survey of Entamoeba gingivalis by multiple sampling in patients with advanced periodontal disease. Int J Parasitol. 1989; 19: 803-808.

28. Bózner P, Demeš P. Degradation of collagen types I, III, IV and V by extracellular proteinases of an oral flagellate Trichomonas tenax. Arch Oral Biol. 1991: 36: 765-770.

29. Cielecka D, Chomicz L, Piekarczyk J, Walski M, Zawadzki PJ, Bednarczyk A, Szubińska D. Oral cavity condition and the occurence of parasitic oral protozoans in patients with genetic diseases. Acta Parasitol. 2000; 45(2): 107-112. 
30. Zawadzki PJ, Perkowski K, Padzik M, Mierzwińska-Nastalska E, Szaflik JP, Conn DB, Chomicz L. Examination of oral microbiota diversity in adults and older adults as an approach to prevent spread of risk factors for human infections. BioMed Res Int. 2017; Article ID 8106491.7 pages. doi: $10.1155 / 2017 / 8106491$

31. Vráblic J, Vondrážka J, Tomová S, Stanik R, Čatár G. Morphology and diagnosis of the oral protozoans Trichomonas tenax and Entamoeba gingivalis using the Giemsa-Romanovsky stain. Bratisl Med L. 1998; 99: 567-572.

32. Zawadzki PJ, Perkowski K, Starościak B, Dybicz M, Baltaza W, Pionkowski K, Chomicz L. Evaluation of selected oral cavity microbiota-risk factors of management complications in patients with masticatory system disorders. Ann of Parasitol. 2016; 62(1): 71-76.

33. Garcia LS. Diagnostic Medical Parasitology. ASM PRESS, Washington, 2005.

34. Murray PR, Baron EJ, Jorgensen JH, Landry ML, Pfaller MA. Manual of clinical microbiology. 9th edition. ASM Press, Washington, USA, 2007.

35. Pietruski JK. Zaburzenia odporności w kandydiazie jamy ustnej. Przegląd piśmiennictwa. Czas Stomatol. 1995; 43:282-286.
36. Fortak B, Płaneta-Małecka I, Trojanowska-Lipczyk J, Czkwianianc E, Dyńska E, Kozieł B. Rola grzybów z rodzaju Candida w etiopatogenezie zapalenia błony śluzowej przełyku, żołądka i dwunastnicy u dzieci. Wiad Parazytol. 2004; 50: 381-386.

37. Kurnatowski P. Niektóre aspekty grzybic wieloogniskowych i uogólnionych. Wiad Parazytol. 2004; 50: 359-365.

38. Ribaux CL, Couble ML, Magloire H, Herbage D. Degradation of type I collagen by Trichomonas tenax: a biochemical study. J Dent Res. 1981; 60: 1202 .

39. Chomicz L, Piekarczyk J, Starościak B, Fiedor P, Piekarczyk B, Szubińska D, Zawadzki PJ, Walski M. Comparative studies on the occurrence of protozoans, bacteria and fungi in the oral cavity of patients with systemic disorders. Acta Parasitol. 2016; 47: 147-153.

40. Chomicz L, Conn DB, Padzik M, Jacek P. Szaflik JP, Walochnik J, Zawadzki PJ, Pawłowski W, Dybicz W. Emerging threats for human health in Poland: pathogenic isolates from drug resistant Acanthamoeba keratitis monitored in terms of their in vitro dynamics and temperature adaptability. BioMed Res Intern. 2015, Article ID 231285, 8 pages. doi: $10.1155 / 2015 / 231285$

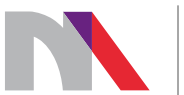

Ministry of Science and Higher Education

Republic of Poland

Generation of the DOI (Digital Object Identifier) - task financed under the agreement No. 618/P-DUN/2019 by the Minister of Science and Higher Education 